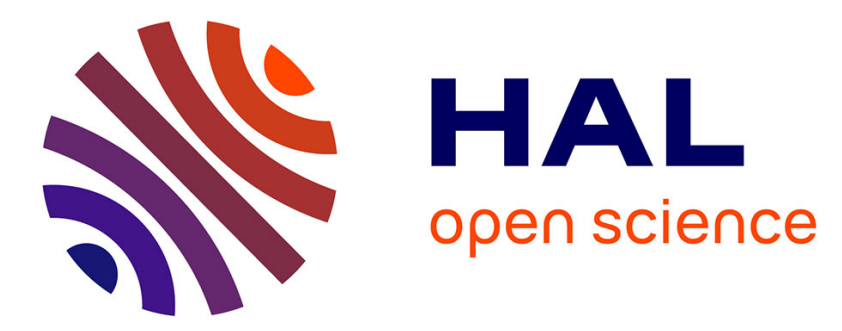

\title{
Kindling molecules: a new way to 'break' the Abbe limit
}

Olivier Haeberle

\section{To cite this version:}

Olivier Haeberle. Kindling molecules: a new way to 'break' the Abbe limit. Comptes Rendus. Physique, 2004, 5, pp.143-148. 10.1016/j.crhy.2003.11.001 . hal-00936081

\section{HAL Id: hal-00936081 \\ https://hal.science/hal-00936081}

Submitted on 24 Jan 2014

HAL is a multi-disciplinary open access archive for the deposit and dissemination of scientific research documents, whether they are published or not. The documents may come from teaching and research institutions in France or abroad, or from public or private research centers.
L'archive ouverte pluridisciplinaire HAL, est destinée au dépôt et à la diffusion de documents scientifiques de niveau recherche, publiés ou non, émanant des établissements d'enseignement et de recherche français ou étrangers, des laboratoires publics ou privés. 
Rubrique : Physique Appliquée, Applied Physics

\title{
Kindling molecules: a new way to "break" the Abbe limit
}

\author{
Olivier HAEBERLÉ
}

Groupe LabEl - Laboratoire MIPS, Université de Haute-Alsace IUT Mulhouse, 61 rue A. Camus F-68093 Mulhouse Cedex France

Abstract Fluorescence microscopy is a key tool for biological investigations. However, compared to other techniques like electron microscopy, the achievable resolution is still limited. Tremendous efforts have been devoted to improve the resolution of far-field optical microscopy. Several techniques do exist, however their adoption by biologists is slowed down by several technical limitations. We propose a new method based on a recently discovered family of optically switchable fluorescent molecules. Kindling proteins opens the way to very high resolution in far-field fluorescence 3-D microscopy with relatively simple techniques.

Fluorescence microscopy, PSF engineering

\section{Les molécules à fluorescence commandable : une nouvelle approche pour "briser" la limite d'Abbe}

Résumé La microscopie de fluorescence est un outil essentiel pour la biologie. Cependant, comparée à d'autres techniques comme la microscopie électronique, la résolution est encore limitée. De nombreuses recherches visent à améliorer cette résolution, et plusieurs techniques existent. Cependant, leur adoption par les biologistes est freinée par de nombreuses contraintes techniques. Nous proposons une nouvelle approche, basée sur une famille de molécules récemment découvertes, dont la fluorescence peut être activée ou inhibée optiquement. Ces moléculés ouvrent la voie à une microscopie de fluorescence $3 \mathrm{D}$ en champ lointain à très haute résolution, de manière relativement simple. 
Microscopie de fluorescence, Ingénierie de la Réponse Impulsionelle Optique

\section{Correspondance:}

Olivier Haeberlé

Groupe LabEl - Laboratoire MIPS, IUT de Mulhouse, 61 rue A. Camus 68093 Mulhouse Cedex Tél : 0389337660 Fax : 0389337605

o.haeberle@uha.fr 


\section{Version française abrégée}

La microscopie de fluorescence s'est imposé comme instrument de choix pour l'étude dynamique des systèmes biologique. Cependant, comparée par exemple à la microscopie électronique, ou aux microscopies en champs proches, la résolution [1] (obtenue à partir d'un modèle scalaire [2] : Eq. 1,2) est limitée. Pour un objectif à ouverture numérique N.A.=1.4, on obtient une résolution latérale de $200 \mathrm{~nm}$ et une résolution longitudinale de $460 \mathrm{~nm}$ à une longueur d'onde d'observation de $450 \mathrm{~nm}$. Cette limite, considérée très longtemps comme infranchissable, suppose cependant que l'ensemble des points de l'objet observé rayonne uniformément. En introduisant la microscopie confocale [3], Marvin Minsky a repoussé les limites. Ses travaux ont suggéré que la limite de résolution n'est en fait pas fixée par le système de détection, mais par le plus petit volume dans lequel on arrive à provoquer l'émission lumineuse.

Diverses approches ont été envisagées : excitation multi-photonique, effets non-linéaires, microscopie Theta [4-6]. Quoique présentant divers avantages, ces méthodes n'améliorent pas fondamentalement la résolution.

La microscopie à rayonnement de transition (Figure 1) a permis d'atteindre une résolution d'environ 100 nm [7-8]. Elle est basée sur le phénomène d'émission lumineuse par une particule chargée traversant une interface [9-11]. Pour des applications biologiques, on retrouve les limitations de la microscopie électronique, à savoir les problèmes de charge du spécimen et la nécessité de travailler sous vide, ce qui exclut les spécimens vivants. Les microscopies à objectifs multiples permettent des gains spectaculaires en résolution [12-14], mais au prix de montages optiques très délicats (Figure 2). La microscopie STED basée sur des effets quantiques dans les fluorophores est très prometteuse [15-18], puisqu'une résolution de $30 \mathrm{~nm}$ en champ lointain a été annoncée [18]. Lorsqu'un colorant est excité, la transition de fluorescence peut avoir lieu spontanément, ou être induite par émission stimulée (Figure 2(a)). L'utilisation de lasers picosecondes permet de différencier le rayonnement induit du rayonnement spontanée émis dans la gamme de la nanoseconde. Un microscope STED est donc essentiellement un microscope confocal modifié, dans lequel le spot d'excitation est suivi très rapidement par un spot STED, qui induit le phénomène de fluorescence sur les bords du spot d'excitation (Figure 3(b)). La fluorescence spontanée ne peut donc être émise que de la partie centrale non affectée du spot d'excitation. Il en résulte donc une réponse impulsionelle optique bien plus petite. Une limitation sévère à l'adoption de cette technique est la nécessité d'utiliser une instrumentation ultrarapide devant être très bien synchronisée, ce qui induit des coûts élevés.

Dmitry Chudakov et ses collègues [19] ont récemment introduit une nouvelle famille de fluorophores, qui présentent la caractéristique unique que leur capacité à fluorescer peut être activée ou désactivée par un 
signal optique (Figure 4). L'état « quenché » et l'état « kindlé » sont les équivalents dans un microscope à fluorescence commandable des états bas et excités dans un microscope STED. Le point important est que ces états sont stables, et que donc une instrumentation ultrarapide n'est plus nécessaire : des transitions de kindling et de quenching de l'ordre de la miliseconde ont été enregistrées. La microsopie à fluorescence commandable offre donc une alternative intéressante à la microscopie STED.

De plus, le principe de fluorescence commandable est compatible avec la microscopie 4Pi et la microscopie STED. La combinaison de ces trois techniques représente un challenge technologique, mais doit permettre d'ouvrir la voie à la nanoscopie en champ lointain. 


\section{Introduction}

Fluorescence microscopy has proven to be an invaluable tool for studying living biological specimens, and is now the instrument of choice for 3-D analysis of cell mechanisms. However, compared for example with scanning electron microscopy or scanning near-field optical microscopy, the resolution of far-field optical microscopy is still limited. Tremendous work is therefore devoted to improve existing instruments, or to find new mechanisms allowing better resolution imaging, by decreasing the size of the Point Spread Function (PSF).

Since the work of Ernst Abbe [1], the fundamental limit that bears his name is considered to constitute the resolution power of far-field microscopy. From scalar diffraction theory [2], one obtains the expression of the intensity Point Spread Function (PSF), and the lateral and longitudinal resolution at full-width half maximum:

$$
\begin{aligned}
& P S F(u, v)=\left|\int_{0}^{1} P(\rho) J_{0}(v \rho) \exp \left(-\frac{1}{2} i u \rho^{2}\right) \rho d \rho\right|^{2} \quad \begin{array}{l}
v=(2 \pi / \lambda) n r \sin \alpha \\
u=(4 \pi / \lambda) n z \sin ^{2}(\alpha / 2)
\end{array} \\
& R_{\text {lat }}=\frac{0.61 \lambda}{\text { N.A. }} \quad R_{\text {long }}=\frac{2 \lambda}{\text { N.A. }^{2}}
\end{aligned}
$$

where $\lambda$ is the wavelength of observation, N.A. the numerical aperture of the objective and $(u, v)$ are optical coordinates [2]. Using oil-immersion objective (N.A.=1.4), and observing at $\lambda=450 \mathrm{~nm}$, a lateral resolution of $200 \mathrm{~nm}$ is achievable, the longitudinal resolution being much lower at $460 \mathrm{~nm}$. For decades, the resolution was limited to these values. However, the Abbe limit assumes that all points of an object emit light in the same manner.

Marvin Minsky brought a first breakthrough by using local illumination, combined with a confocal detection to give birth to the confocal microscope [3]. The resolution is mostly improved by the fact that local illumination ensures that neighboring points do not radiate in the same manner, and a resolution of $130 \mathrm{~nm}$ laterally and of $320 \mathrm{~nm}$ longitudinally is obtained for N.A.=1.4 and $\lambda=450 \mathrm{~nm}$. His work suggested in fact that the resolution is not limited by the detection system, but by the smallest volume one can produce, where light emission occurs.

Numerous approaches have been proposed, using multi-photon excitation [4], second-harmonic generation (SHG) [5], crossed illumination and detection in Theta microscopy [6], or combinations of these techniques. Some techniques offer better penetration depths (multi-photon), or give access to other structural information (SHG), but the resolution is not fundamentally increased.

Three types of far-field optical microscopy have hitherto proven to deliver a much higher resolution than the Abbe criterion. We shall first give a brief description of their principles, and enlighten some of their 
limitations, which explain that these techniques are not yet routinely used, and then propose a new technique, which promises similar results, but with easier means.

\section{Transition Radiation Microscopy}

Transition radiation microscopy [7-8] makes use of the light emitted by a charged particle crossing the interface separating two media with different optical properties [9]. The distribution of the emitted light is given for flat surfaces by the classical Pafomov expressions, which have recently been generalized to rough surfaces [10]. When using low energy particles, the radiation distribution is very wide, allowing an easy detection. Figure 1 sketches transition radiation microscopy.

When focusing the detector onto the surface hit by the particles, it is possible to measure the beam spatial dimensions. When focusing at infinity, one can measure the beam divergence. As a consequence, the primary use of this effect has been for charged beam diagnostic, using metallic mirrors as radiators.

A very interesting property, specific to this effect, is that photons are emitted at the exact location where the particle hit the surface [11]. Contrary to a beam diagnostic system in which the characteristic of the radiator are well known, and those of the electron beam are under studies, if the position of the beam is well known, and its size is very small, a resolution much below the Abbe criterion is achievable to investigate the radiator properties.

This prediction has been confirmed by Naoki Yamamoto and his colleagues [7-8]. Combining a scanning electron microscope, using the very narrow electron beam provided by this instrument, with an optical detection set-up, they obtained an optical, far-field resolution close to $100 \mathrm{~nm}$. Limitations are however crippling for biology: vacuum operation and specimen charging exclude working on living cells. Furthermore, transition radiation being a surface effect, 3-D analysis are not possible. Limitations are indeed those of electron microscopy.

\section{Multiple-Objective Microscopies}

Multiple Objective Microscopes make use of interference effects to decrease the PSF [12,13]. The best results have been obtained using two high numerical objectives, facing each other in the so-called $4 \mathrm{Pi}$ configuration. Figure 2 describes the optical set-up. When coherent illumination using a laser beam and confocal coherent detection of the fluorescence signal are simultaneously used, the best results are 
obtained, in a $4 \mathrm{Pi}$ type $\mathrm{C}$ configuration.

Spectacular gains are obtained with 4Pi microscopy, the resolution being improved to $70 \mathrm{~nm}$ longitudinally and $120 \mathrm{~nm}$ laterally (theoretical results), but at the price of a much increased complexity of the optical setup. The illumination setup complexity is reduced by the fact the optical paths do not have to be exactly the same, thanks to the high coherence length of lasers. For the detection however, the optical paths have to be identical within the typical coherence length of fluorescence, namely within about $20 \mu \mathrm{m}$ [14], therefore requiring a very sensitive optical alignment. Furthermore, the necessity to observe the specimen from both sides obliges to mount it between two cover glass, resulting in delicate manipulations. These drawbacks probably explain the low adoption of this ten years old technique.

\section{STED Microscopy}

STED microscopy, a recently proposed new technique promises to push the limit even further $[15,16]$. In this approach, quantum effects are used to avoid the fluorescence process at undesired places effectively reducing the actual size of the point spread function (PSF). Stephan Hell and his associates demonstrated the process in a modified confocal microscope. Figure 3(a) shows a typical energy level diagram for an organic fluorophore. Excitation generates the $\mathrm{L}_{0} \rightarrow \mathrm{L}_{1}$ transition. Fluorescence is described by the $\mathrm{L}_{2} \rightarrow$ $\mathrm{L}_{3}$ radiative transition. Using picosecond lasers, it is possible to excite the fluorophore at a much faster rate than regular fluorescence, which occurs in the nanosecond range. It is also possible to induce the $\mathrm{L}_{2}$ $\rightarrow \mathrm{L}_{3}$ transition by stimulated emission by using a second picosecond beam, which emission matches the energy gap between $\mathrm{L}_{2}$ and $\mathrm{L}_{3}$.

The principle of STED microscopy is described in Figure 3(b). The first step consists in rapidly exciting the fluorophore by a focused beam, like in a confocal microscope. While the molecules lay in an excited state, a second, hollow beam (STED beam) stimulates the emission of the excited molecules at the outer edges of the spot [16]. Regular fluorescence therefore occurs only from the central hollow beam position, resulting in a much smaller fluorescent spot. Resolution near $100 \mathrm{~nm}$ in 3-D has been obtained [16]. While still subject to discussion [17], even better results have been reported: by combining 4Pi and STED microscopy a longitudinal resolution of $30 \mathrm{~nm}$ has been achieved [18].

One advantageous feature of STED microscopy comes from the fact that a STED microscope is essentially a modified confocal microscope (if the STED beam is switched off, regular confocal microscope images are acquired). Therefore, contrary to 4Pi or Theta microscopy, classical sample preparation and manipulation may be used. However, one possible limitation to wide adoption of STED microscopy is the use of ultra-fast components: the excitation and STED beams, and the detector must 
indeed be synchronized within a few picoseconds. These stringent requirements induce high costs.

\section{Kindling Microscopy}

A simple explanation of the improved resolution in confocal microscopy is provided by a probabilistic interpretation of the detection process. In a classical microscope, the probability for a photon to reach the detector is given by the product of the probability of the photon to be created (equal to one, because of the uniform excitation) by the probability for the photon to be detected $\mathrm{P}_{\mathrm{d}}$, given by Eq. (1). In a confocal microscope, the probability of excitation $\mathrm{P}_{\mathrm{f}}$ is also given by Eq. (1), so that the PSF of a confocal microscope is in first approximation simply given by squaring the PSF of the classical microscope. In transition radiation microscopy, the probability of emission is non-zero (and null elsewhere) only over the spatial extension of the electron beam, which size can be much smaller than an Airy spot. In STED microscopy, the probability of emission is decreased at specific places by the stimulated emission process.

With this interpretation, any mechanism able to prevent the fluorescence process, and therefore decrease the probability of emission at the outer edges of the excitation spot would be suitable to decrease the global PSF. However, in order to form an image by scanning the specimen, only mechanisms resulting in a reversible inhibition of the fluorescence are useful.

Dmitry Chudakov and his co-workers [18] recently introduced new proteins exhibiting the unique feature of being normally non-fluorescent, but able to fluoresce after illumination by green light (Helium-Neon laser line at $543 \mathrm{~nm}$ ), as well as being quenched by exposition to blue light (Argon laser line at $458 \mathrm{~nm}$ ). The process can be irreversible or reversible depending on the initial illumination intensity.

The authors emphasized the use of this "kindling fluorescent protein" (KFP1) for precise in vivo photolabeling, by enabling or quenching the fluorescence emission on demand while tracking the fluorescent-able molecules. Another very promising application in the field of high-resolution microscopy should attract the interest of biologists and physicists. Figure 4 shows the state diagram of such molecules. When in a kindled state, the diagram is the same as of a regular fluorescent molecule. But in a quenched state, no fluorescence can occur.

Kindling fluorescence microscopy therefore permits simpler designs than STED microscopy. Exciting KFP1 molecules with green light as in a confocal microscope a fluorescent-able spot is produced. The spatial probability distribution of fluorescence kindling $\mathrm{P}_{\mathrm{k}}$ is given by Eq. (1), computed at $\lambda_{\text {kindling }}$.

Then, using a blue hollow beam to quench the outer molecules to their non-fluorescing state, a much narrower kindling spot will result, similarly to STED microscopy. The probability of quenching $\mathrm{P}_{\mathrm{q}}$ is a 
function of the hollow spot intensity distribution, computed at $\lambda_{\text {quenching }}$.

In a third step, the small resulting kindling spot is excited by a confocal beam, and will give rise to fluorescence emission, with probability $\mathrm{P}_{\mathrm{f}}$ given by Eq. (1), computed at $\lambda_{\text {excitation }}$.

Note that the reduction of the fluorescence spot in kindling microscopy is favored by the fact that the quenching wavelength is shorter than the kindling wavelength, contrary to STED microscopy, involving a STED beam of longer wavelength than the excitation beam. As a consequence, the hollow beam for quenching is smaller than the hollow beam for STED. Another advantage is that kindling microscopy being a three-step process, the final excitation PSF results from a three-term multiplication $\left(\mathrm{P}_{\mathrm{k}} *\left(1-\mathrm{P}_{\mathrm{q}}\right) * \mathrm{P}_{\mathrm{f}}\right)$, while in STED microscopy, the final excitation PSF results from a two-term multiplication $\left(\mathrm{P}_{\mathrm{f}}^{*}\left(1-\mathrm{P}_{\text {sted }}\right)\right.$, $\mathrm{P}_{\text {sted }}$ being the probability of depleting the excited state by stimulated emission. As a consequence, an even smaller final PSF will result. The important point is that kindling states being stable, ultra fast instrumentation is not needed: kindling and quenching in the millisecond range have been reported [18]. Finally, the STED mechanism may still be applied to the kindling spot, in a four step excitation process $\mathrm{P}_{\mathrm{k}}^{*}\left(1-\mathrm{P}_{\mathrm{q}}\right) * \mathrm{P}_{\mathrm{f}}^{*}\left(1-\mathrm{P}_{\text {sted }}\right)$ and $4 \mathrm{Pi}$ microscopy is also compatible with these processes. Combining these three techniques represents a very tough technical challenge, but would result in an even more drastically reduced excitation PSF.

\section{Conclusion}

With kindling microscopy, we have proposed a new, probably more affordable, way to very highresolution fluorescence microscopy, which should help to satisfy, for one, the needs of biologists for extremely detailed in vivo imaging. Furthermore, a combination of 4Pi, Kindling and STED microscopy may pave the way to far-field nanoscopy.

\section{References}

1. Abbe E., Arch. Mikrosk. Anat. 9, 413-468 (1873)

2. Born M. and Wolf E., Principles of Optics, $6^{\text {th }}$ ed., Pergamon, London (1991)

3. Minsky M., Scanning 10, 128-138 (1988).

4. Denk W., Strickler J.H. and Webb W.W., Science 248, 73-75 (1990)

5. Moreaux L., Sandre O. and Mertz J., JOSA B 17, 1685-1694 (2000)

6. Stelzer E. H. K. and Lindek S., Opt. Commun. 111 (1994) 536

7. Yamamoto N. and Toda A., Scanning Microsc. 9, 669-676, (1995) 
8. Yamamoto N., Toda A. and Araya K., J. Electron Microsc 45, 64-72 (1996)

9. Ter-Mikaelian M.L., High-Energy Electromagnetic Processes in Condensed Media, Wiley (1972)

10. Takakura Y. and Haeberlé O., Phys. Rev. E 61, 4441-4444 (2000)

11. Artru X., Chehab R., Honkavaara K. and Vaiola A., Nucl. Instr. Meth. B 145, 160-168 (1998)

12. Hell S.W. and Stelzer E. H. K., Opt. Comm. 93, p.277 (1992)

13. Haeberlé O., Xu C., Dieterlen A. and Jacquey S., Compt. Rend. Acad. Sc. IV (Paris) 2 (2001) 1509

14. Hell S. W., "Increasing the resolution of far-field fluorescence light microscopy by point-spreadfunction engineering" in Topics in Fluorescence Spectroscopy; Vol. 5: Nonlinear and Two-PhotonInduced Fluorescence, J. Lakowicz ed., Plenum Press, New York (1997)

15. Hell S. W. and Wichmann J., Opt. Lett. 19, 780-782 (1994)

16. Klar T. A., Jakobs S., Dyba M., Egner A. and Hell S.W., Proc. Natl. Acad. Sci. USA 97, 8206-8210 (2000)

17. Stelzer, E. H. K., Nature 416, 806-807 (2002)

18. Dyba M. and Hell S. W. Phys. Rev. Lett. 88, 163901 (2002).

19. Chudakov, D.M. et al., Nature Biotechnology 21, 191-194 (2003) 


\section{Figure Captions}

Figure 1: Principle of transition radiation microscopy: a very narrow electron beam, with diameter much smaller than an optical illumination spot permits precise localisation of the point where transition radiation is emitted. Transition radiation is collected and refocused onto a detector. Resolution is therefore limited by the electron beam size and stability.

Figure 1 : Principe de la microscopie à rayonnement de transition : un faisceau d'électrons très étroit, de dimension bien plus faible que la tache d'Airy permet de localiser très précisément le point d'où le rayonnement de transition est émis. Le rayonnement de transition est collecté et refocalisé sur un détecteur. La résolution est donc limitée par la taille du faisceau d'électron et sa stabilité.

Figure 2: Scheme of a 4Pi type $\mathrm{C}$ confocal microscope. The specimen is illuminated by two focused laser beams, interfering at the common focal point of both objectives. The fluorescence signal is collected by both objectives, and is coherently detected.

Figure 2 : Shema d'un microscope 4Pi type C. Le specimen est illuminé par deux faisceaux laser focalisés, interférants au point focal commun des deux objectifs. Le signal de fluorescence est collecté par les deux objectifs, et est détecté de manière cohérente.

Figure 3: (a): energy level diagram of an organic fluorophore. After excitation (transition $\mathrm{L}_{0} \rightarrow \mathrm{L}_{1}$ ), fluorescence occurs: transition $\mathrm{L}_{2} \rightarrow \mathrm{L}_{3}$. This transition can also be induced by stimulated emission. (b): STED microscopy: the excitation signal give birth to a small excited spot; then, before regular fluorescence occurs, a STED beam stimulated the emission at the outer edges of the excited spot. Regular fluorescence can therefore occurs only from the small central, unaffected zone, resulting in a much narrower Point Spread Function.

Figure 3 : (a) : diagramme d'energie d'un fluorophore organique. Après excitation (transition $\mathrm{L}_{0} \rightarrow \mathrm{L}_{1}$ ), le signal de fluorescence spontanée est émis : transition $\mathrm{L}_{2} \rightarrow \mathrm{L}_{3}$. Cette transition peut aussi être stimulée.

(b) : microscopie STED : le signal d'excitation donne naissance à un petit spot excité ; peu après, avant que la fluorescence soit émise, un faisceau STED stimule l'émission sur les bords du spot excité. La fluorescence spontanée ne peut donc être émise que de la partie centrale, non-affectée du spot excité. Il en résulte donc une PSF bien plus petite.

Figure 4: state diagram of a kindling fluorophore. The transition from the quenched to the kindled state is reversible. In the kindled state, regular fluorescence may be induced. Quenched and kindled states are the equivalent in a Kindling microscope to the ground and excited state in a STED microscope.

Figure 4 : diagramme d'état d'un colorant à fluorescence commandable. La transition de l'état "quenché" à l'état "kindlé" est réversible. Ces états sont les équivalents dans un microscope à fluorescence commandable des états de repos et excité dans un microscope STED. 


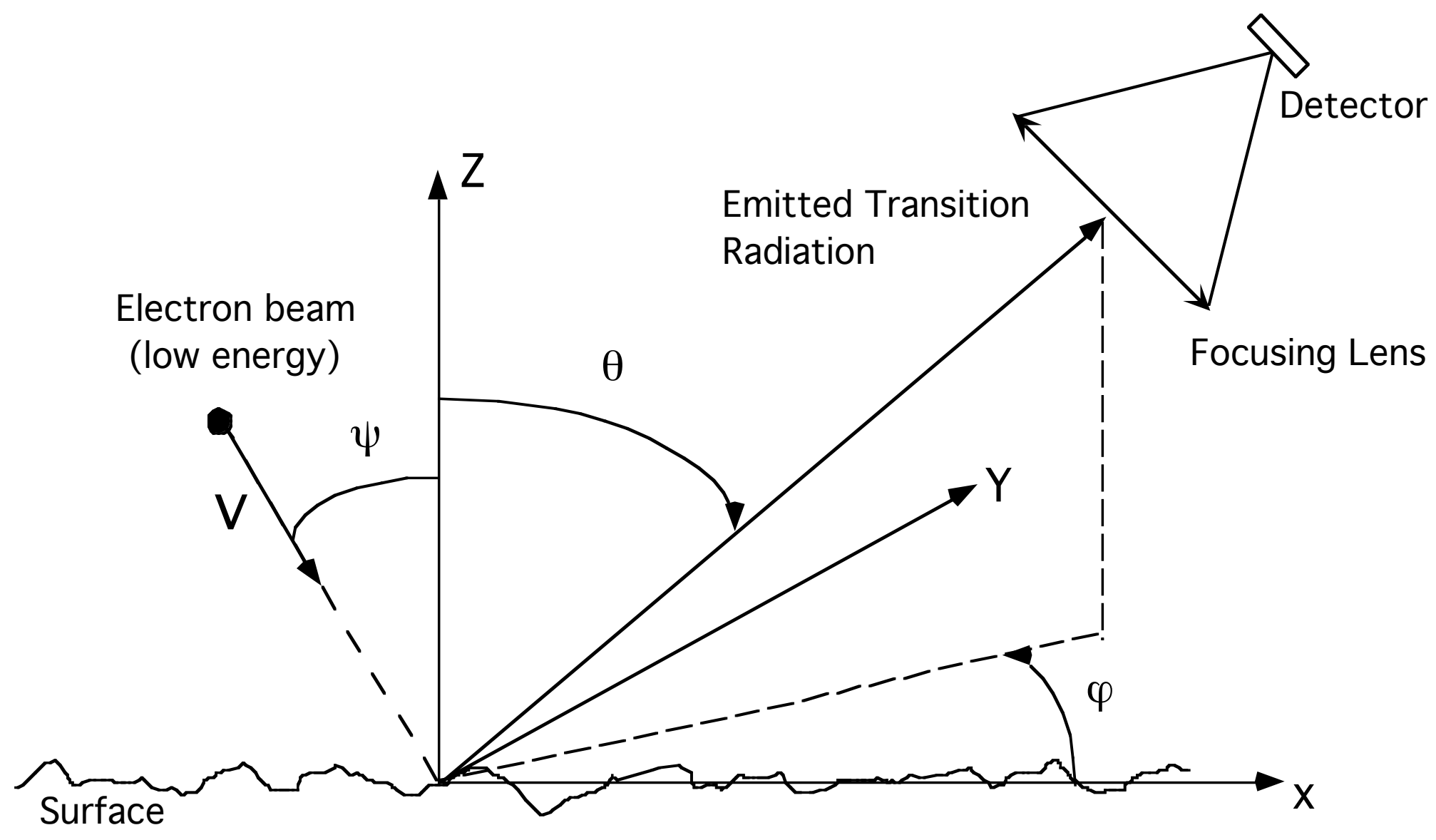

O. Haeberlé "Kindling molecules: a new way to "break" the Abbe limit" Figure 1 


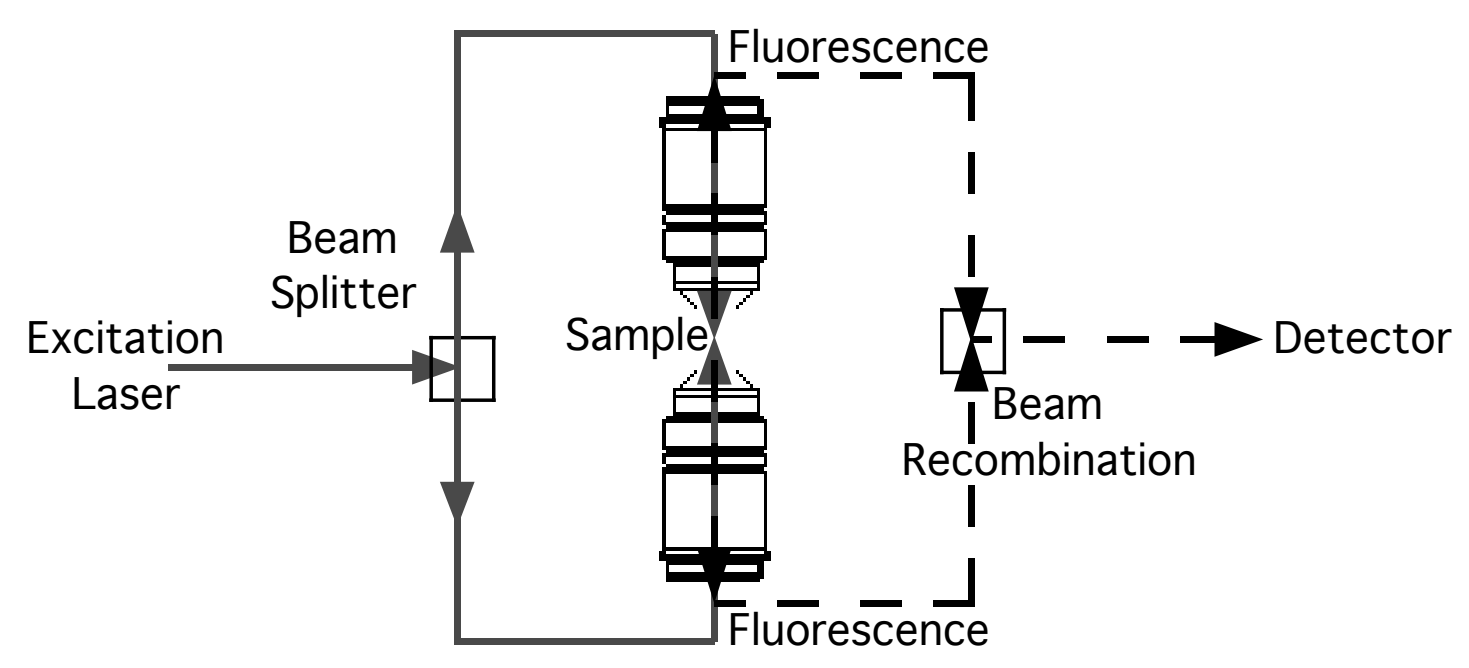

O. Haeberlé et al. "Kindling molecules: a new way to "break" the Abbe limit" Figure 2 


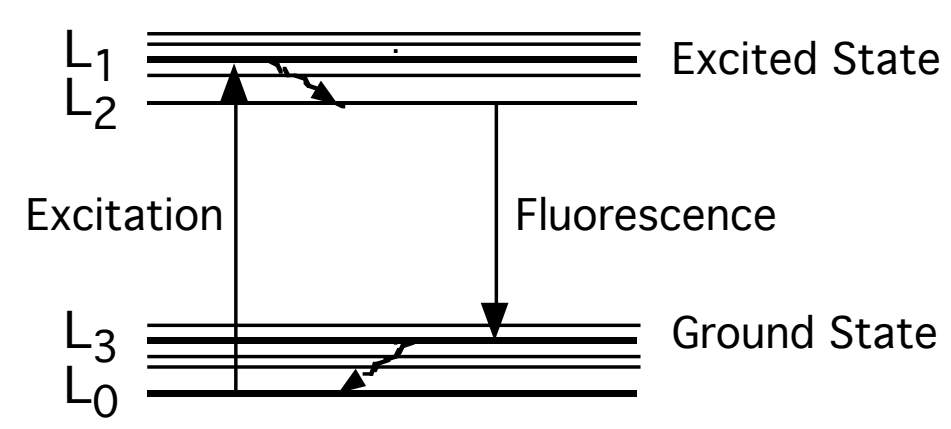

O. Haeberlé et al. "Kindling molecules: a new way to "break" the Abbe limit" Figure 3(a) 


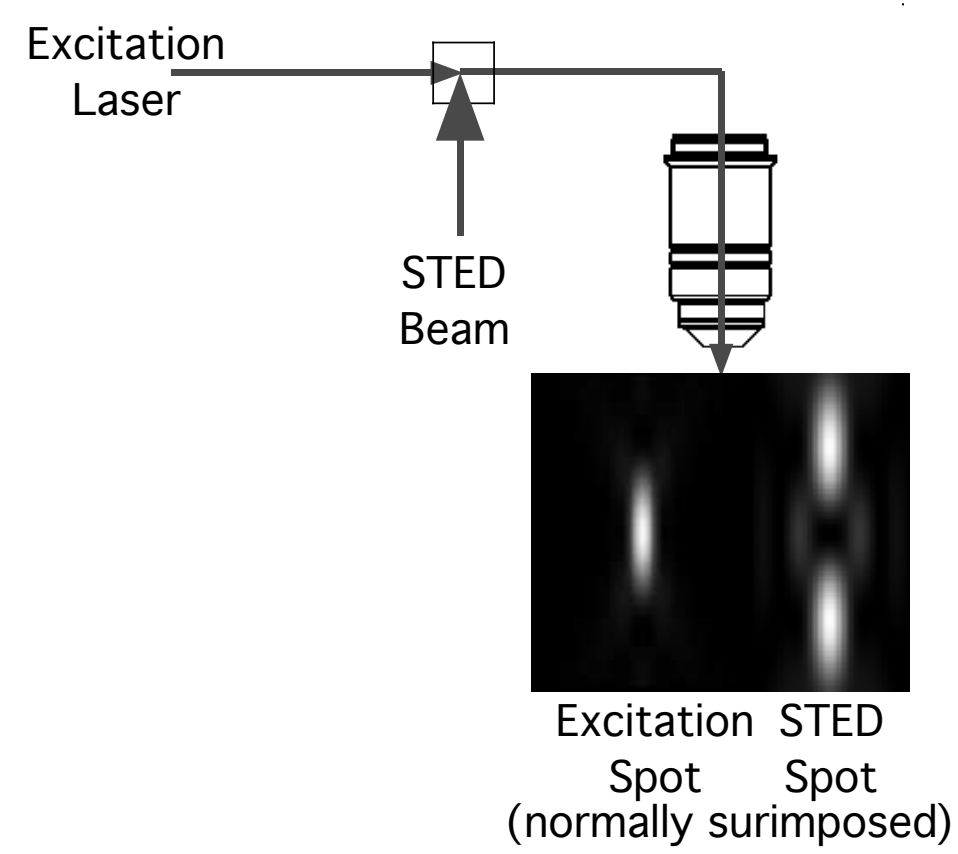

O. Haeberlé et al. "Kindling molecules: a new way to "break" the Abbe limit" Figure 3(b) 


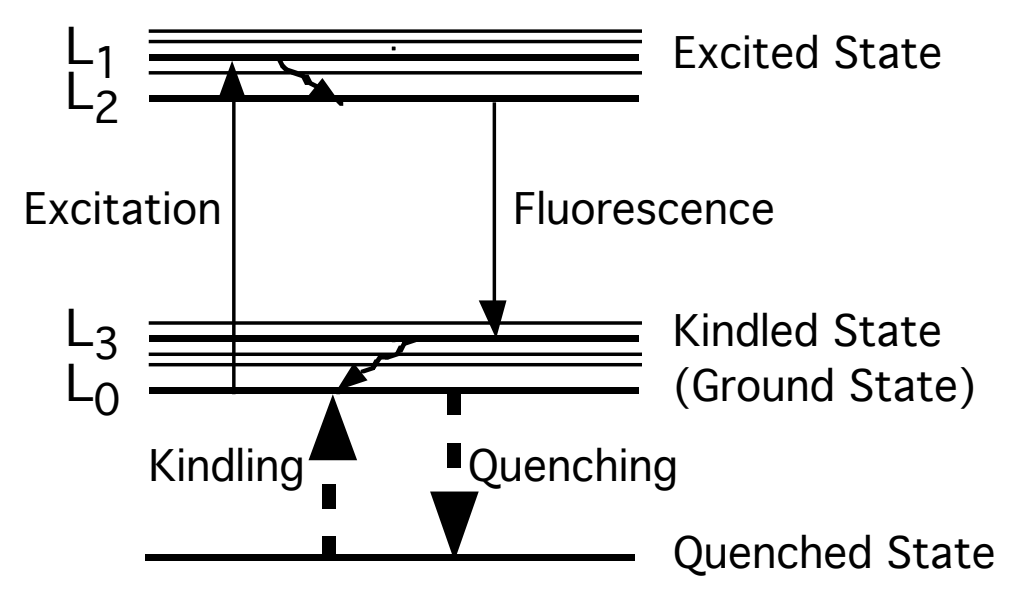

O. Haeberlé et al. "Kindling molecules: a new way to "break" the Abbe limit" Figure 4 